\title{
Isolation of 12 polymorphic tetranucleotide microsatellite markers of the leaf beetle Ophraella communa, a promising Ambrosia biocontrol agent also in Europe
}

\author{
François Bordeyne, Heinz Müller-Schärer and Sarah Bouchemousse \\ Department of Biology, University of Fribourg, Fribourg, Switzerland
}

\begin{abstract}
Following its first record in Europe in 2013, the North American ragweed leaf beetle Ophraella communa, used already as a most successful biocontrol agent against common ragweed in China, is spreading rapidly, asking for a detailed analysis of the potential benefit and risk of this introduction for Europe. Here, we report twelve specific and polymorphic tetranucleotide microsatellite markers, which can be used for redrawing its global invasion history and spread across native and introduced ranges. The high level of polymorphism (i.e. from 4 to 18 alleles per locus) and the genetic variation detected within and between one native and two introduced populations provide adequate statistical power for elucidating the beetle's invasion process.
\end{abstract}

\section{KEYWORDS}

Biological control agent;

Chrysomelidae; Ophraella communa; microsatellites; multiplex PCRs; population genetics

The North American common ragweed, Ambrosia artemisiifolia L. (Asteraceae), is one of the most prominent plant invaders worldwide (Essl et al., 2015). In Europe, the plant is the cause of high economic losses due to severe impacts on human health resulting from its huge amount of highly allergenic pollen and because it is an important and hard-tocontrol crop weed (Essl et al., 2015; Müller-Schärer et al., 2014). In its native range, common ragweed is the preferred host plants of Ophraella communa LeSage 1986 (Coleoptera: Chrysomelidae), an oligophagous leaf beetle endemic to North America, distributed from Mexico to the Canadian Prairies. This leaf beetle was accidentally introduced in Eastern Asia almost two decades ago, where it is now used in China as a most successful biological control agent against common ragweed (Müller-Schärer et al., 2014). Since its recent and accidental introduction into Western Europe, with first records in Southern Switzerland and the Milano area (Italy) in 2013, local aerial pollen concentrations of $A$. artemisiifolia have significantly dropped by $80 \%$ compared to noninfested areas (Bonini et al., 2015). This steep decline in pollen concentration, where O. communa is present, made this insect a most promising candidate for long-term management of common ragweed also in Europe (Müller-Schärer et al., 2014). Following its fast spread south of the Alps (Zadravec, Horvatic, \& Prpic, 2019), multiple studies have been initiated to determine, whether this beetle should be considered as a troublesome

CONTACT Sarah Bouchemousse sarah.bouchemousse@gmail.com D Department of Biology/Ecology and Evolution, University of Fribourg, Chemin du musée 10, 1700 Fribourg, Switzerland 
introduction or whether it is likely to become the first case of a successful biological control of an invasive weed in continental Europe.

To identify the source population(s) of the introduction in Europe and to monitor the future spread of the ragweed leaf beetle genotypes, it is essential to know the extent and structure of the neutral genetic diversity of O. communa populations in both the native and the introduced ranges. Here, we report a set of twelve polymorphic tetranucleotide microsatellite markers that will be useful to investigate the invasion processes of O. communa.

The whole genome sequence (ca. 92,800 raw sequences) of a genomic DNA pool of two males and two females, collected in the two introduced ranges, i.e. China (Shenzhen: $22^{\circ}$ $32^{\prime} 10.032^{\prime \prime} \mathrm{N}, 114^{\circ} 03^{\prime} 44.459^{\prime \prime} \mathrm{E}$; Wuhan: $\left.30^{\circ} 32^{\prime} 42.029^{\prime \prime} \mathrm{N}, 114^{\circ} 25^{\prime} 14.739^{\prime \prime} \mathrm{E}\right)$ and Italy

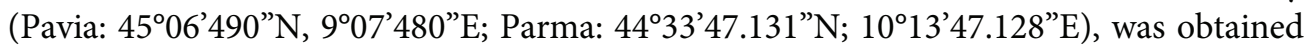
from paired-end reads of 250 base pairs (bp) sequenced on a MiSeq ${ }^{\circ}$ Next Generation Sequencer v.2 (Illumina) (Microsynth platform, Balgach, Switzerland). Following bioinformatics processing (i.e. de-novo assembly, detection of microsatellite motifs and primer pairs performed by the Microsynth platform), a total of 5,338 sequences containing microsatellite motifs were delivered, including $306 \mathrm{di}-$, tri- and tetra-nucleotide loci with suitable primer pairs. Although the number of alleles is usually reduced in tetra-nucleotide loci compared to di- and tri-nucleotide loci, they are generally easier to detect and display less slippage artifacts. Primer pairs of 53 tetra-nucleotide loci, displaying at least 7 repeat units, were therefore tested for amplification, polymorphism and congruence of motif repetitions using a 6-FAM M13 tail (cf. Schuelke (2000) for details of the procedure). Tests were performed on a set of 16 individuals collected in both native and introduced ranges (Appendix 1). As a result, eight of the 53 loci tested were monomorphic, nine loci did not yield amplification products and 16 displayed uninterpretable amplification patterns. The remaining 20 loci were then tested for allele inheritance using two leaf beetle couples collected in Italy and 12 of their offspring (i.e. six per couple, produced in the quarantine facilities at the University of Fribourg, Switzerland). At the end of the selection procedure, twelve promising tetra-nucleotide microsatellite markers were chosen for developing multiplex PCRs. Multiplex PCRs are simultaneous amplifications of several sequences by using multiple primer pairs, each branded by a fluorescent dye, in a reduced number of reaction mixtures. To allow the annealing of multiple primer pairs, we used a touchdown PCR method by programming a range of temperatures in the PCR protocols. In summary, we developed three multiplexes and three simplexes in this study, each with specific temperature conditions and primer concentrations (see Table 1 for more details).

Once the development of the PCRs was achieved, polymorphisms of the 12 loci were estimated in one native and two introduced populations (Table 2). To do so, genomic DNA of 20-24 individuals per population were extracted using a customised sbeadex ${ }^{\mathrm{TM}}$ kit (LGC). Locus amplification was performed following the optimised PCRs developed upstream (Table 1). PCR reactions were performed in a total volume of $15 \mu \mathrm{L}$ containing $2 \mu \mathrm{L}$ of template DNA (ca. $20 \mathrm{ng}$ of genomic DNA), $1 \mathrm{X} \mathrm{GoTaq}{ }^{\circledR}$ Reaction Buffer with $0.5 \mathrm{U}$ of GoTaq ${ }^{\circ}$ G2 DNA polymerase (Promega), $0.25 \mathrm{mM}$ of each $\mathrm{dNTP}, 1 \mathrm{mg} / \mathrm{mL}$ of bovine serum albumin, as well as reverse primers at $0.2 \mu \mathrm{M}$ and forward primers in locus-specific concentrations (Table 1). All PCRs were performed with a TProfessional thermocycler (Biometra) using the following conditions: an initial denaturation phase at $95^{\circ} \mathrm{C}$ for 
Table 1. Details of the 12 microsatellite loci of Ophraella communa and amplification conditions of multiplex PCRs.

\begin{tabular}{|c|c|c|c|c|c|c|c|c|c|}
\hline \multirow[b]{2}{*}{ Locus name $^{\#}$} & \multirow[b]{2}{*}{ GenBank Accession Number } & \multirow[b]{2}{*}{ Primer sequences $\left(5^{\prime}->3^{\prime}\right) \mathrm{F}$ : Forward, R: Reserve } & \multirow[b]{2}{*}{$\begin{array}{c}\text { Repeat } \\
\text { motif }\end{array}$} & \multirow[b]{2}{*}{$\begin{array}{c}\text { Size } \\
\text { range (bp) }\end{array}$} & \multirow[b]{2}{*}{$\begin{array}{l}\text { Multiplex } \\
\text { PCR Number }\end{array}$} & \multirow[b]{2}{*}{$\begin{array}{l}\text { Temperature } \\
\text { conditions }\end{array}$} & \multirow[b]{2}{*}{$\begin{array}{l}\text { Fluorescent } \\
\text { dye }(*)\end{array}$} & \multicolumn{2}{|c|}{$\begin{array}{l}\text { Forward } \\
\text { primer final } \\
\text { concent- } \\
\text { rations }\end{array}$} \\
\hline & & & & & & & & $\begin{array}{l}\mathrm{F}^{*} \\
(\mu \mathrm{M})\end{array}$ & $\begin{array}{c}\mathrm{F} \\
(\mu \mathrm{M})\end{array}$ \\
\hline Ocom_Q51 & MN167543 & $\begin{array}{l}\text { F: GCACAATAGGTCTCATAGATCGC } \\
\text { R: AGCCATGGTGGAGGTTACTG }\end{array}$ & $(\text { CATA })_{13}$ & $132-242$ & 1 & $\begin{array}{l}\text { TD: } 62-56^{\circ} \mathrm{C}\left(6 \mathrm{C} .,-1^{\circ} \mathrm{C} / \mathrm{C} .\right) \\
\text { AM: } 56^{\circ} \mathrm{C}(20 \text { c. })\end{array}$ & Atto532 & 0.12 & 0.08 \\
\hline Ocom_Q38 & MN167542 & $\begin{array}{l}\text { F: TITATAGACACAGCTGAACTCC } \\
\text { R: ACATGCCATTCTITTAGGTTTIG }\end{array}$ & $(\text { AATA })_{7}$ & $121-145$ & 1 & & Atto550 & 0.15 & 0.05 \\
\hline Ocom_Q18 & MN167537 & $\begin{array}{l}\text { F: TTITATCTTGGCACTGGCGG } \\
\text { R: GGACTTTAGGAGGCAAAAAGTGG }\end{array}$ & $(\mathrm{TCTT})_{9}$ & $128-204$ & 1 & & FAM & 0.12 & 0.08 \\
\hline Ocom_Q05 & MN167534 & $\begin{array}{l}\text { F: CGTGTTCTACATTTATTACGTTITGC } \\
\text { R: CATGGCAAGTAAGGGGACAC }\end{array}$ & $(\mathrm{ATGT})_{8}$ & $169-181$ & 1 & & Atto565 & 0.10 & 0.10 \\
\hline Ocom_Q37 & MN167541 & $\begin{array}{l}\text { F: AGGGATTTCTAAAATGCAGTTGG } \\
\text { R: GAACATGGCAAGTAAGGGGG }\end{array}$ & $(\text { TATG })_{15}$ & $155-251$ & 2 & $\begin{array}{l}\text { TD: } 65-55^{\circ} \mathrm{C}\left(10 \mathrm{C.},-1^{\circ} \mathrm{C} / \mathrm{C} .\right) \\
\text { AM: } 55^{\circ} \mathrm{C}(20 \mathrm{c.} .)\end{array}$ & Atto532 & 0.08 & 0.12 \\
\hline Ocom_Q25 & MN167538 & $\begin{array}{l}\text { F: GCTGCTAGGACCTGTACCATC } \\
\text { R: GCATCTGGACCCGTATTCTTG }\end{array}$ & $(\text { TATC })_{12}$ & $192-220$ & 2 & & Atto550 & 0.05 & 0.15 \\
\hline Ocom_Q02 & MN167532 & $\begin{array}{l}\text { F: AGCCCGACGATGTCCTAAAC } \\
\text { R: CCAACGTGGGGTTATACGAAG }\end{array}$ & $(\mathrm{ACAT})_{9}$ & $208-232$ & - & AM: $52^{\circ} \mathrm{C}(23 \mathrm{c})$. & FAM & 0.12 & 0.08 \\
\hline Ocom_Q31 & MN167540 & $\begin{array}{l}\text { F: GAACATGGCAAGTAAGGGGG } \\
\text { R: GAACTTGGGCCGTAAACCAG }\end{array}$ & $(\text { CATA })_{10}$ & $230-306$ & - & AM: $52^{\circ} \mathrm{C}(23 \mathrm{c})$. & Atto565 & 0.10 & 0.10 \\
\hline Ocom_Q27 & MN167539 & $\begin{array}{l}\text { F: ACAAATGGTAAGGCGTTTGC } \\
\text { R: TGCCTGGAATCCGTAAGAGG }\end{array}$ & $(\text { TGTA })_{13}$ & $151-223$ & 3 & $\begin{array}{l}\text { TD: } 64-54^{\circ} \mathrm{C}\left(10 \mathrm{C.},-1^{\circ} \mathrm{C} / \mathrm{c} .\right) \\
\text { AM: } 54^{\circ} \mathrm{C}(20 \text { c.) }\end{array}$ & Atto532 & 0.12 & 0.08 \\
\hline Ocom_Q07 & MN167535 & $\begin{array}{l}\text { F: TCGCAGTGTACTGATCACCC } \\
\text { R: TACTCACGAAGCGTCTCCAG }\end{array}$ & $(\text { CATA })_{8}$ & $208-240$ & 3 & & Atto550 & 0.05 & 0.15 \\
\hline Ocom_Q08 & MN167536 & $\begin{array}{l}\text { F: TCACGTTCAATGTCATAGCG } \\
\text { R: AGCAATTATGTACTGAACTCTTGTG }\end{array}$ & $(\mathrm{TAGA})_{8}$ & $158-178$ & 3 & & FAM & 0.10 & 0.10 \\
\hline Ocom_Q04 & MN167533 & $\begin{array}{l}\text { F: AAGAGCTTTCGCATGTTGTG } \\
\text { R: AACTTCTTTGGAGGCGTCGG }\end{array}$ & $(\text { TATC })_{7}$ & $202-222$ & - & AM: $52^{\circ} \mathrm{C}(23 \mathrm{c})$. & Atto565 & 0.10 & 0.10 \\
\hline
\end{tabular}

"The names of loci were defined by the abbreviation of the species name (Ocom for Ophraella communa), the number of base pairs in the repeat motifs (Q for "quattuor") and a number between 1
and 53 corresponding to the number of primer pairs tested in this study. Both touchdown (TD), amplification (AM) temperatures and number of cycles (c.) are given for each multiplex PCR. The
two temperatures given for the touchdown correspond to the initial and final temperatures. The concentrations of fluorescent (F*) and non-fluorescent (F) forward primers are marker-specific. 
Table 2. Genetic polymorphisms of the 12 microsatellite loci of Ophraella communa in one native and two introduced populations, and cross-amplification success on Ophraella slobodkini.

\begin{tabular}{|c|c|c|c|c|c|c|c|c|c|c|c|c|c|c|}
\hline \multirow[b]{3}{*}{ Locus name } & \multirow[b]{3}{*}{ Total $\mathrm{N}_{\mathrm{A}}$} & \multicolumn{4}{|c|}{ Native population } & \multicolumn{8}{|c|}{ Introduced populations } & \multirow{3}{*}{$\begin{array}{c}\text { Cross-amplification } \\
\text { (O. slobodkini) } \\
\text { Ferndale, USA }(n=11) \\
28^{\circ} 37^{\prime} 45.300^{\prime \prime} \mathrm{N}, 81^{\circ} \\
41^{\prime} 43.908^{\prime \prime} \mathrm{W} \\
\mathrm{N}_{\mathrm{A}}\end{array}$} \\
\hline & & \multicolumn{4}{|c|}{$\begin{array}{l}\text { Falmouth, USA }(n=20) 38^{\circ} 20^{\prime} 15.684^{\prime \prime} \mathrm{N}, 77^{\circ} \\
\qquad 29^{\prime} 6.180^{\prime \prime} \mathrm{W}\end{array}$} & \multicolumn{4}{|c|}{$\begin{array}{c}\text { Wanjia, China }(n=24) 29^{\circ} 27^{\prime} 50.868^{\prime \prime} \mathrm{N}, 13^{\circ} \\
25^{\prime} 27.551^{\prime \prime} \mathrm{E}\end{array}$} & \multicolumn{4}{|c|}{$\begin{array}{l}\text { Ponte San Pietro, Italy }(n=22) 45^{\circ} 41^{\prime} 40.236^{\prime \prime} \mathrm{N} \text {, } \\
\qquad 9^{\circ} 35^{\prime} 29.759^{\prime \prime} \mathrm{E}\end{array}$} & \\
\hline & & $\mathrm{N}_{\mathrm{A}}$ & $\mathrm{Ho}$ & $\mathrm{He}$ & $F_{I S}$ & $\mathrm{~N}_{\mathrm{A}}$ & Ho & $\mathrm{He}$ & $F_{I S}$ & $\mathrm{~N}_{\mathrm{A}}$ & $\mathrm{Ho}$ & $\mathrm{He}$ & $F_{I S}$ & \\
\hline Ocom_Q51 & 18 & 14 & 0.35 & 0.91 & $0.621^{* \neq} \neq$ & 4 & 0.21 & 0.59 & $0.654^{*, \neq}$ & 7 & 0.14 & 0.78 & $0.820^{*, \neq}$ & 0 \\
\hline Ocom_Q38 & 7 & 7 & 0.85 & 0.73 & -0.166 & 2 & 0.04 & 0.04 & 0.000 & 4 & 0.48 & 0.58 & 0.184 & 1 \\
\hline Ocom_Q18 & 16 & 16 & 0.53 & 0.93 & $0.441^{*, \neq}$ & 4 & 0.14 & 0.53 & $0.748^{*, \neq}$ & 7 & 0.73 & 0.81 & 0.102 & 0 \\
\hline Ocom_Q05 & 4 & 4 & 0.17 & 0.70 & $0.768^{* \neq}$ & 2 & 0.18 & 0.24 & 0.250 & 3 & 0.27 & 0.42 & 0.349 & 0 \\
\hline Ocom_Q37 & 14 & 12 & 0.85 & 0.90 & 0.056 & 3 & 0.63 & 0.52 & -0.206 & 8 & 0.68 & 0.80 & 0.149 & 0 \\
\hline Ocom_Q25 & 7 & 5 & 0.26 & 0.67 & $0.612^{*, \neq}$ & 3 & 0.17 & 0.44 & $0.629^{*, \neq}$ & 2 & 0.10 & 0.18 & 0.465 & 0 \\
\hline Ocom_Q02 & 6 & 5 & 0.29 & 0.64 & $0.548^{*, \neq}$ & 4 & 0.21 & 0.63 & $0.670^{*, \neq}$ & 5 & 0.26 & 0.67 & $0.612^{*, \neq}$ & 0 \\
\hline Ocom_Q31 & 12 & 11 & 0.60 & 0.91 & $0.349^{*, \neq}$ & 1 & NA & NA & NA & 6 & 0.65 & 0.79 & 0.181 & 0 \\
\hline Ocom_Q27 & 13 & 9 & 0.45 & 0.89 & $0.502^{*, \neq}$ & 5 & 0.29 & 0.67 & $0.573^{*, \neq}$ & 5 & 0.30 & 0.75 & $0.605^{*, \neq}$ & 0 \\
\hline Ocom_Q07 & 6 & 6 & 0.39 & 0.71 & $0.460^{*, \neq}$ & 2 & 0.05 & 0.48 & $0.898^{*, \neq}$ & 3 & 0.45 & 0.61 & 0.254 & 0 \\
\hline Ocom_Q08 & 6 & 6 & 0.58 & 0.75 & $0.237^{*}$ & 2 & 0.39 & 0.45 & 0.132 & 4 & 0.33 & 0.59 & $0.444^{*}, \neq$ & 0 \\
\hline Ocom_Q04 & 4 & 3 & 0.21 & 0.57 & $0.636^{*, \neq}$ & 2 & 0.39 & 0.48 & 0.182 & 2 & 0.11 & 0.29 & 0.636 & 0 \\
\hline $\begin{array}{l}\text { Average } \\
( \pm \text { SD) }\end{array}$ & $9.4 \pm 4.9$ & $8.2 \pm 4.2$ & $0.46 \pm 0.23$ & $0.78 \pm 0.13$ & - & $2.8 \pm 1.2$ & $0.25 \pm 0.17$ & $0.46 \pm 0.18$ & - & $4.7 \pm 2.0$ & $0.38 \pm 0.22$ & $0.61 \pm 0.21$ & - & - \\
\hline
\end{tabular}

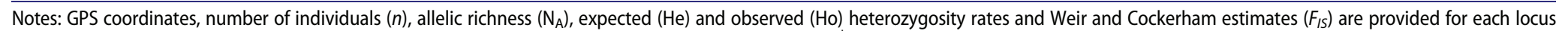

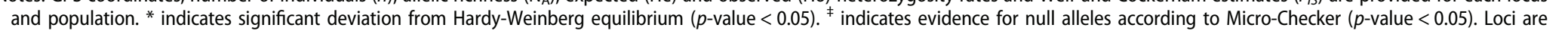
sorted in the same order as in Table 1. 
5 min, followed by $6-10$ touchdown cycles, with each cycle consisting of a denaturation at $95{ }^{\circ} \mathrm{C}$ for $30 \mathrm{~s}$, annealing for $45 \mathrm{~s}$ with specific step-downs temperatures (Table 1), and elongation at $72^{\circ} \mathrm{C}$ for $45 \mathrm{~s}$; touchdown cycles were immediately followed by $20-23$ amplification cycles, with each cycle consisting of a denaturation at $95^{\circ} \mathrm{C}$ for $30 \mathrm{~s}$, annealing at primer-specific temperatures for $45 \mathrm{~s}$ (Table 1), and elongation at $72^{\circ} \mathrm{C}$ for $45 \mathrm{~s}$; a final elongation phase at $72^{\circ} \mathrm{C}$ for $10 \mathrm{~min}$ finished the PCR programmes. For the genotyping, $1 \mu \mathrm{L}$ of PCR products was added to a mix containing $9.7 \mu \mathrm{L}$ of formamide and $0.3 \mu \mathrm{L}$ of DNA Size Standard 500 Orange (Nimagen). An ABI 3130xl capillary sequencer (Applied Biosystems) was used to separate PCR fragments. The sizes of fragments, corresponding to the alleles, were scored using GeneMarker v.2.7.2 (SoftGenetics, State College, Pennsylvania, USA). Finally, following the same procedure, cross-priming was tested on 11 individuals of Ophraella slobodkini Futuyma, 1991, a species sharing host association of A. artemisiifolia with O. communa and living in sympatry in Georgia and South Carolina, USA (Futuyma, 1991).

For each locus and each of the three O. communa populations, allele scoring allowed us to determine both allelic richness (i.e. number of allele) and allele frequencies, as well as the number of heterozygote individuals (i.e. individuals displaying two different alleles at a given locus). Then, using the R package Genepop v.1.1.2 (Rousset, 2008), observed (Ho) (Eq. 1) and expected (He) (Eq. 2) heterozygosity rates were computed for each locus and population, as:

$$
\begin{gathered}
\text { Ho }=\frac{\text { Number of heterozygotes }}{\text { Number of individuals }} \\
\mathrm{He}=1-\sum_{i=1}^{k} p i^{2}
\end{gathered}
$$

where $p_{i}$ is the frequency of the ith of $k$ alleles for a given locus.

Linkage disequilibrium (i.e. non-random association of alleles at different loci) and deviation from Hardy-Weinberg equilibrium (i.e. constancy of genotype and allele frequencies over generations), based on Weir and Cockerham estimate, $F_{I S}$ (Weir \& Cockerham, 1984), were also tested per locus and population using the Genepop R package (Rousset, 2008). For both tests, $p$-values were adjusted based on the false discovery rate to account for multiple testing errors. The presence of null alleles was then examined per locus and population with Micro-Checker v.2.2.3 (Van Oosterhout, Hutchinson, Wills, \& Shipley, 2004).

Across all populations, the allelic richness per locus ranged from 4 to 18, with an average of $9.4 \pm 4.9$ alleles per locus (see Table 2 for more details). At a regional level, allele richness per locus tended to be higher in the native population compared to the introduced ones. For instance, 11 alleles were reported at the Ocom_Q31 locus in the native population, which dropped to six and one allele in the Italian and Chinese population, respectively. The same pattern was found for both observed and expected heterozygosity rates: for instance, on average across all loci, expected heterozygosity rates amounted to $0.78 \pm 0.13$ for the North-American population and decreased to $0.61 \pm$ 0.21 and to $0.46 \pm 0.18$ for the Italian and Chinese population, respectively. These findings indicate a reduced number of population sources and/or introduction events in the introduced ranges and are in line with the results of Nishide et al. (2015) for Japanese 
populations of O. communa using mitochondrial sequences. Post-introduction genetic bottlenecks or founding events commonly occur in introduced populations and might have further contributed to the reduced genetic diversity observed in our two introduced populations. Further genetic studies using the microsatellite markers developed here and including additional native and introduced Asian and European populations will allow to better understand the invasion history of the ragweed leaf beetle worldwide.

Significant linkage disequilibrium was detected for only one pair of loci out of 179 (for Ocom_Q37 \& Ocom_Q38 in the Italian population). Interestingly, several microsatellites showed a significant deviation from Hardy-Weinberg equilibrium. These deviations, due to a deficit in heterozygosity, were found both in native (10 out of 12 loci) and introduced populations ( 4 and 6 out of 12 loci for the Italian and Chinese population, respectively). Such heterozygosity deficits have been reported for several Coleopteran species (e.g. McKeown et al., 2018) and may result from biological processes, such as selection, inbreeding or Wahlund effects (i.e. sampling of individuals from genetically distinct groups). Knowing that all populations were randomly sampled (i.e. leaf beetles were collected on more than 50-100 A. artemisiifolia plants using sweep nets), inbreeding and Wahlund effects are unlikely, but cannot be excluded. While both reasons do not impair the development of microsatellite markers, upcoming genetic population studies must implement an appropriate sampling design to avoid genetic relatedness and local genetic clustering. A more reliable explanation of heterozygosity deficits is the presence of null alleles resulting from nucleotide variations of flanking regions that can prevent primer annealing during PCR amplification. Here, Micro-checker results confirmed evidence of null alleles for the majority of the markers deviating from Hardy-Weinberg equilibrium (Table 2). Null alleles are often unavoidable in species showing large effective population sizes and short generation time, such as O. communa (Müller-Schärer et al., 2014), resulting in an overestimation of population differentiation (Chapuis \& Estoup, 2007). However, the occurrence of null alleles varies across geographic regions (i.e. $75 \%, 50 \%$ and $33 \%$ of microsatellite null alleles were detected with Micro-checker in the native and in the introduced Chinese and Italian population, respectively), allowing to choose region-specific microsatellite markers for further population genetic studies.

Cross-priming amplification failed for almost all of the microsatellite markers (Table 2). Therefore, these markers cannot be used to assess phylogenetic relationships and population genetic diversity and structure of other Ophraella species. Only the Ocom_Q38 locus successfully amplified in O. slobodkini with a single allele detected. Interestingly, this allele (113 bp) was not observed in the studied O. communa populations (from 121 to $145 \mathrm{bp}$ ), suggesting that this marker may be used as a diagnostic to separate the two species and to evaluate potential hybridizations, in addition to the genetic markers already developed by Futuyma (1991).

The development of these microsatellite markers offers an efficient and cost-effective tool to assess the genetic diversity and structure of native and introduced populations of O. communa, as well as identifying the sources of introduced populations, the number of introduction events and the process of expansion following introductions. In addition, the set of markers will be useful for pre- (e.g. identification of host associations) and post-release assessments (e.g. evolutionary changes), and thus help scientists and decision-makers to implement optimal management strategies using this promising biocontrol candidate against the notorious and widespread common ragweed. 


\section{Acknowledgements}

We thank B. Augustinus, Z. Jialiang, Y. Sun and P. Toth for sample collections. We are also grateful to Ecogenics for the sequencing and primer design and to G. Jacob for constructive discussions on microsatellite choice and the development of multiplex PCRs.

\section{Disclosure statement}

No potential conflict of interest was reported by the authors.

\section{Funding}

This work was supported by the Swiss National Science Foundation to HMS [number: 31003A_166448].

\section{References}

Bonini, M., Sikoparija, B., Prentovic, M., Cislaghi, G., Colombo, P., Testoni, C., ... Smith, M. (2015). Is the recent decrease in airborne Ambrosia pollen in the Milan area due to the accidental introduction of the ragweed leaf beetle Ophraella communa? Aerobiologia, 31(4), 499-513. doi:10. 1007/s10453-015-9380-8

Chapuis, M.-P., \& Estoup, A. (2007). Microsatellite null alleles and estimation of population differentiation. Molecular Biology and Evolution, 24(3), 621-631. doi:10.1093/molbev/msl191

Essl, F., Biro, K., Brandes, D., Broennimann, O., Bullock, J. M., Chapman, D. S., ... Follak, S. (2015). Biological Flora of the British Isles: Ambrosia artemisiifolia. Journal of Ecology, 103(4), 10691098. doi:10.1111/1365-2745.12424

Futuyma, D. J. (1991). A new species of Ophraella Wilcox (Coleoptera, Chrysomelidae) from the southeastern United-states. Journal of the New York Entomological Society, 99(4), 643-653.

McKeown, N. J., Harvey, D. J., Healey, A. J. E., Skujina, I., Cox, K., Gange, A. C., \& Shaw, P. W. (2018). Isolation and characterisation of the first microsatellite markers for the European stag beetle, Lucanus cervus (Coleoptera: Lucanidae). European Journal of Entomology, 115, 620623. doi:10.14411/eje.2018.059

Müller-Schärer, H., Lommen, S. T. E., Rossinelli, M., Bonini, M., Boriani, M., Bosio, G., \& Schaffner, U. (2014). Ophraella communa, the ragweed leaf beetle, has successfully landed in Europe: Fortunate coincidence or threat? Weed Research, 54(2), 109-119. doi:10.1111/wre.12072

Nishide, Y., Fukano, Y., Doi, H., Satoh, T., Inoue, H., \& Boriani, M. (2015). Origins and genetic diversity of the ragweed beetles, Ophraella communa (Coleoptera: Chrysomelidae), that were introduced into Italy and Japan based on an analysis of mitochondrial DNA sequence data. European Journal of Entomology, 112(4), 613-618. doi:10.14411/eje.2015.086

Rousset, F. (2008). Genepop '007: A complete re-implementation of the Genepop software for Windows and Linux. Molecular Ecology Resources, 8(1), 103-106. doi:10.1111/j.1471-8286. 2007.01931.x

Schuelke, M. (2000). An economic method for the fluorescent labeling of PCR fragments. Nature Biotechnology, 18, 233-234. doi:10.1038/72708

Van Oosterhout, C., Hutchinson, W. F., Wills, D. P. M., \& Shipley, P. (2004). MICRO-CHECKER: Software for identifying and correcting genotyping errors in microsatellite data. Molecular Ecology Notes, 4(3), 535-538. doi:10.1111/j.1471-8286.2004.00684.x

Weir, B. S., \& Cockerham, C. (1984). Estimating F-statistics for the analysis of population structure. Evolution, 38(6), 1358-1370.

Zadravec, M., Horvatic, B., \& Prpic, P. (2019). The Balkans invaded - first record of Ophraella communa LeSage, 1986 (Coleoptera: Chrysomelidae) in Croatia. BioInvasions Records, 8(3), 521-529. doi:10.3391/bir.2019.8.3.07 


\section{Appendix 1. Populations selected to test primer pairs of the 53 tetra- nucleotide loci, using a set of 16 individuals (with $\mathbf{2}$ individuals per population).}

\begin{tabular}{|c|c|c|c|c|}
\hline Location & Country & Date of sampling & Collector(s) & GPS coordinates (latitude, longitude) \\
\hline Wuhan & China & $2015-08-31$ & Zhang Jialiang & $\begin{array}{l}30^{\circ} 32^{\prime} 42.029^{\prime \prime} \mathrm{N} \\
114^{\circ} 25^{\prime} 14.739^{\prime \prime} \mathrm{E}\end{array}$ \\
\hline Shenzhen & China & 2017-07-29 & Heinz Müller-Schärer, Yan Sun & $\begin{array}{l}22^{\circ} 32^{\prime} 10.032^{\prime \prime} \mathrm{N} \\
114^{\circ} 03^{\prime} 44.459^{\prime \prime} \mathrm{E}\end{array}$ \\
\hline Pavia & Italy & 2015-08-13 & Peter Toth & $\begin{array}{c}45^{\circ} 06^{\prime} 49.000^{\prime \prime} \mathrm{N} \\
9^{\circ} 07^{\prime} 48.000^{\prime \prime} \mathrm{E}\end{array}$ \\
\hline Parma & Italy & $2015-08-31$ & Benno Augustinus & $\begin{array}{c}44^{\circ} 33^{\prime} 47.131^{\prime \prime} \mathrm{N} \\
10^{\circ} 13^{\prime} 47.128^{\prime \prime} \mathrm{E}\end{array}$ \\
\hline Providence (SC) & USA & 2016-10-01 & Heinz Müller-Schärer, Yan Sun & $\begin{array}{l}33^{\circ} 22^{\prime} 56.244^{\prime \prime} \mathrm{N}, \\
80^{\circ} 30^{\prime} 49.680^{\prime \prime} \mathrm{W}\end{array}$ \\
\hline Gordonville (VA) & USA & 2016-10-04 & Heinz Müller-Schärer, Yan Sun & $\begin{array}{c}38^{\circ} 08^{\prime} 42.396^{\prime \prime} \mathrm{N} \\
78^{\circ} 11^{\prime} 0.455^{\prime \prime} \mathrm{W}\end{array}$ \\
\hline Baltimore (MD) & USA & 2016-10-05 & Heinz Müller-Schärer, Yan Sun & $\begin{array}{l}39^{\circ} 14^{\prime} 29.724^{\prime \prime} \mathrm{N}, \\
76^{\circ} 34^{\prime} 47.892^{\prime \prime} \mathrm{W}\end{array}$ \\
\hline Springfield (MA) & USA & 2016-10-06 & Heinz Müller-Schärer, Yan Sun & $\begin{array}{l}42^{\circ} 08^{\prime} 57.084^{\prime \prime} \mathrm{N}, \\
72^{\circ} 29^{\prime} 46.391^{\prime \prime} \mathrm{W}\end{array}$ \\
\hline
\end{tabular}

